\title{
The Ages of Dickens in Estonian Literature. Some Comparative Perspectives with \\ a Marxist Exposure
}

\author{
ARNE MERILAI
}

\begin{abstract}
This paper offers some Dickensian comparative reflections as they appear in the mirror of Estonian culture. First, it opens up a line of inquiry aimed at the reception of Dickens' works in Estonian translation. Secondly, this contribution elucidates salient developments of a peripheral modern culture in the Victorian era, namely the formation of a newly formed literature, exemplified by its most prominent authors and epic Kalevipoeg, and the emergence of a suppressed nation from the shadows of Baltic-German rule in the Russian Empire. Thirdly, this paper sheds light on the first Estonian novelist, socialist Eduard Vilde. It offers an intriguing way of thinking, about his humorous writing, post-romantic sentiment and its transformation into critical realism during and after the fin de siècle. As an added and in broad terms related point of interest, the paper concludes with an original illuminative chart. It encompasses the formal core of Marxist thought which still informs some contemporary approaches such as feminism or postcolonialism.
\end{abstract}

Keywords: Charles Dickens, dickensianism, literary reception, Estonian literature, comparativism, criticism of Marxism

\section{Introduction}

Two years ago, in February, we should have celebrated the $200^{\text {th }}$ anniversary of Charles Dickens' birth - alas, we hardly did. ${ }^{1}$ In spite of the sinister silence, many of us still know what the notion Dickensian denotes, namely: depicting poverty, distress, and exploitation; the grotesquely comic; the picturesque, vivid; a post-romantic sentimental realism; the occasionally vague, odd Pickwickian style of expression.

1 This contribution is based on the initial paper delivered at the Literary London Charles Dickens Symposium at the Oxford and Cambridge Club, December 15-17, 2012.

For the slide show of the article see http://www.ut.ee/ amerilai/Estonian Dickensianism.pdf (retrieved 01. 07. 2014). 
This shared knowledge may form an elucidating point of departure for the purpose of introducing Estonian literature, as something unfamiliar, to an international audience. Thus, this article would offer some Dickensian comparative reflections as they appear in the mirror of our culture. First, it opens up a line of inquiry aimed at the reception of Dickens' works in Estonian translation. Secondly, it reveals some developments of a peripheral modern culture in the Victorian era, the formation of a newly formed literature, exemplified by its most prominent authors and works, including epic Kalevipoeg and Eduard Vilde's post-romantic sentiment in its transformation into critical realism. And, thirdly, as an added point of possible interest and further reflection, the paper concludes with an original chart illuminating the formal core of Marxist thought, which still informs some contemporary approaches such as feminism or postcolonialism, providing a reasonable basis for their criticism.

Accordingly, I could also rephrase my threefold agenda as follows. First, Estonian literature during the lifespan of Dickens; that is, metaphorically speaking: "The Era of Struggle of Tiny Oliver Twist for His Very Existence". Second, the times of Eduard Vilde half a century later, which may be called: "The Fight of Oliver Twist as a Young Man for His Very Independence" (after the events of the novel, of course). And, thirdly, as for the Marxist model of civil society and how did it actually work, the title for an appendix could be: "The Observations and Testimony by Oliver Twist in the Court of Law; or, Where Was Fagin's Gold Hidden”.

\section{The Reception of Charles Dickens in Estonia}

In the $19^{\text {th }}$ century, as an educated society, Estonia was completely Germanspeaking, with some Czarist Russian bureaucratic obligations. Consequently, the first wave of the reception of Dickens in Estonia took place mainly via the German translations: there is a complete set of his writings, particularly German doppelgängers, in bulky editions stored in the University of Tartu Library. ${ }^{2}$ We can also find a sole fragment of a letter with Dickens' signature (Broadstairs, Kent, $20^{\text {th }}$ August 1847), probably an auction item, located in the archive of a contemporary collector Friedrich Ludwig Schardius (1795-1855). ${ }^{3}$

\footnotetext{
2 Alas, the reference lists that old are not available in the online catalogue of the University of Tartu library (http://www.utlib.ee/index.php?chlang=eng).

3 http://tartu.ester.ee/record=b1353866 S1 ${ }^{*}$ est, retrieved 01.19.2013.
} 
MERILAI

However, the Estonian-speaking population made its first acquaintance with Dickens in their mother tongue as late as in 1882 when A Christmas Carol was published in a pamphlet form (Jõulu ôhtu, literally: A Christmas Night: After English Poet Dickens: Narrated into Estonian Language by J. Kõrw). ${ }^{4}$ After some random adaptations, his first novel, The Posthumous Papers of the Pickwick Club, was released as a serial (alas, uncompleted, as the daily was banned for a while), as late as in 1907. ${ }^{5}$ Ever since Dickens has become a well-read classic with the Estonian readers, writers and critics of different generations; maybe less enthusiastically as it happened in Lithuania, but still. Nevertheless, some of his main achievements, like Bleak House, Hard Times, Little Dorrit or Our Mutual Friend, are still missing in our culture. Perhaps a peculiar fact worth mentioning is that during the grim era of Stalinism Dickens, in spite of being a western author, enjoyed the favour of communist censorship as his pen was once keenly praised by Karl Marx himself, for the benefit of our hungry postwar audience.

The following is an informative list of Dickens's translations in Estonian. ${ }^{6}$ The numbers of the years printed in bold (alongside with the titles of works and names of translators) may be considered as more significant; the years of reprints or retranslations are square bracketed.

A Christmas Carol (adaptation), translated by Jakob Kõrv - 1882 [full text 1993, translated by Helga Kross; adaptations 1999, 2001; staged 2009]

Random adaptations, fragments: “The Drunkard's Death” (literally) - 1888; "Tyrol Girl" (literally) - 1899; "Family Secret" (literally), translated by Nikolai Waas - 1898 [1903]; "Friend of Truth" (literally) - 1911

The Posthumous Papers of the Pickwick Club, partly translated by J. Lill (=Anton Jürgenstein) - 1907 [full text 1948, translated by Marta Sillaots] (staged 1978)

"Swains: London Merry Tales" (literally): Mr. Watkins Tottle, Horatio Sparkins, Sentiment (from Sketches by Boz), translated by Mihkel Neumann - 1913

4 Jõuluõhtu: Inglise luuletaja Dickens'ijärele. Eestikeelde jutustanudJ. Kõrw [=Jakob Kõrv]. (Tallinn: Th. Jakobson, 1882.) Eesti Kirjameeste Seltsi Toimetused. Eesti Kirjawara Nr. 15.

5 Pikwiklased ehk herra Pikwiki ja Pikwik-klube kirjawahetajate liikmete rist- ja põiksõidud, imelikud juhtumised ja teod. Inglise kirjaniku Charles Dickens'i järele J. Lill [=Johann Lill [Jürgenstein]], Postimees: Eesti päewaleht, No. 1-147, 01.02.1907 07.03.1907 (http://dea.nlib.ee/index.php?lid=1\&byea=1907, retrieved 01.07.2014).

6 A concise overview, alas with reckless shortcomings in text and bibliography, was published last year by Suliko Liiv and Julia Tofantšuk (2013). For example, they are not aware that the first novel of Dickens in Estonian translation was The Pickwick Club (1907), and not the partial version of Martin Chuzzlewit (1914). 
The Life and Adventures of Martin Chuzzlewit (partly, translator unknown) 1914 [full text 1963, translated by Elvi Kippasto and Valda Raud]

The Cricket on the Hearth (adapted play), translated by William Toomingas 1920, [1926, story, translated by E. Vöhlman; 1993, translated by Helga Kross] (many stagings since 1920)

The Haunted Man and the Ghost's Bargain - 1925 [2005]

The Adventures of Oliver Twist, translated by Hans Freimann - 1927 [1964, translated by Koidu Reim; 2001] (staged 1935, 2003)

"Nell and her Grandfather" (from The Old Curiosity Shop), translated by Hello Ahlberg - 1932

Dombey and Son (partly), translated by Oskar Truu - 1933

David Copperfield, translated by Marta Sillaots - 1937 [1991, translated by Lia Rajandi and Marta Sillaots; 2007 $]^{7}$

The Life of Our Lord: Written for His Children, translated by Kusta Martinson - 1937 [1992]

The Chimes, translated by Helga Kross - 1993

The Magic Fishbone, translated by Enn Randma - 1995

Great Expectations, translated by Asta Blumenfeld - 1997

Nicholas Nickleby (musical adaptation, unpublished), translated by Anne Lange - staged 1997

A Tale of Two Cities (adaptation), translated by Jana Linnart - 2000

"Best Ghost Stories" (literally): The Queer Chair, A Madman's Manuscript, The Story of the Goblins Who Stole a Sexton, The Ghosts of the Mail, The Baron of Grogzwig, The Haunted Man, To Be Read at Dusk, The Ghost in the Bride's Chamber, The Haunted House, The Trial for Murder, The Signalman; translated by Aulis-Leif Erikson - 2005

To be Taken with a Grain of Salt, translated by Triin Sinissaar - 2009

\section{Estonian Literature at the Times of Dickens (1812-1870)}

Estonia was known for its rich runo song folklore. However, regarding written literature, apart from ecclesial books, before the birth of Dickens, only occasional didactic narratives and poetry had emerged in Estonian (which

\footnotetext{
Although Liiv and Tofantšuk insist twice on the opposite (2013: 511, 513), the novel David Copperfield was never staged in Estonia, not by Georg Malvius (who directed Nicholas Nickleby in 1997 and Oliver! in 2003) nor anybody else. However, both the Swedish musical director and the famous namesake, American illusionist David Copperfield happened to act in Tallinn at the same time in December 2004. Still, to date there are indeed three musicals based on the novels of Dickens that have been performed in Estonia as the opera Pickwick Club, by Georgian composer Grigory Shantyr, was staged in Vanemuine Theatre in 1978 by Kaarel Ird.
} 
MERILAI

even lacked adequate formal grammar), mostly by the Estophile Lutheran pastors and barons. These attempts were mainly of a Pietistic and Sentimental nature. As a rule and with few exceptions, such efforts remained aesthetically quite insignificant.

In contrast, baroness Barbara Juliane von Krüdener (1764-1824) "persisted for 200 years in all the reference books of the world" (Sachris 2004, see also Phillips 1911), and Wikipedia today. One of her portraits, by Angelica Kauffmann, is still hanging in the Louvre, Paris. The lady, a mother of five, who had been a lover of Emperor Aleksander I of Russia himself, but a pietist visionary prophet in her late days, was a daughter of Russian senator von Vietinghoff, a leading freemason, probably the richest man in historical Livonia (that is South Estonia and North Latvia nowadays).

Von Krüdener published an autobiographic sentimental novel Valérie (1804), in French, inspired by actress Lady Hamilton's Emma persona, influenced byJean-Jacques Rousseau's Julie or New Héloise, Goethe's The Sorrows of Young Werther, La Rochefoucauld's Memoirs, Pierre Choderlos de Laclos's The Dangerous Liaisons, and lord Byron. The plot of the all-European bestseller is conceived in Venice, and consists of a Swedish nobleman's confessional love letters to his friend from Italy; sensual Valérie is the author's alter ego. The novel got a very good reception, among the supporters Bernardin de SaintPierre, Charles-Augustin Sainte-Beuve, Mme de Staël, Chateaubriand, and Achim von Arnim. Valérie had an impact on no lesser figures than Alexandr Pushkin, Honore de Balzac, and Marcel Proust later, although Napoleon and Goethe both fiercely rejected the work.

Actually, Goethe did so with respect to the plays of his former associate Jakob Michael Reinhold Lenz (1751-1792), too, another Baltic-German literary talent among the lesser, a member of the Sturm und Drang movement. Der Hofmeister (The Tutor, 1774) and Die Soldaten (The Soldiers, 1776) were his most famous innovative, "open form” (Klotz 1960) dramas which inspired Georg Büchner, Bertolt Brecht, Paul Celan and many others in the next century (Salumets 1991). All these pieces were, of course, not written in the vernacular language, but they definitely belong to Estonian literature.

The year Dickens was born, in 1812, the Kayserliche Universität Dorpat, today renowned as the University of Tartu, was reopened by Alexander I of Russia. This major temple of education, crucial to the mental individuation of Estonians, was initially founded as Academia Gustaviana Dorpatensis in 1632 by the Swedish king Gustav II Adolph. Thus, from the $17^{\text {th }}$ century on, there are piles of academic poetry written in Latin and Greek, hardly studied yet (see Viiding, Orion, Päll 2007). Alas, this noble tradition was abandoned at the beginning of the $18^{\text {th }}$ century as the university ceased to exist for a lengthy 
period due to the devastating Great Northern War, between Carl of Sweden and Peter the Great. As a result, Estonia was cut off from the Swedish Kingdom and incorporated into the Russian Empire.

When Dickens was born, the future genius and initiator of Estonian literary poetry Kristian Jaak Peterson (1801-1822) was eleven years old already in the middle of his short life like a blazing comet (Merilai 2004a). The works of this enthusiastic student of theology were powerful, full of intense, glorious imagery. He studied in Riga and Tartu University hoping to become a Christian missionary among the Red Indian or African tribes. A young poet, he excelled in many languages, translated from Greek, Swedish, and published on linguistic matters and Finnish mythology. Albeit his own verse creation remained mainly in manuscript form almost for a century, except a couple of poems published in Leipzig where he was hoping to move ahead and establish himself as a man of letters.

Peterson's Horacean, or Miltonian, Klopstockian and Höltyan, euphoric Pindaric litanies and Anacreontic sensual pastorals, full of up and down movement between earth and sky, energetic verbs and gerunds, and a philosophical diary are a mixture of classicism, pre-Romantism and post-Leibnitzian theosophy, bold stoicism and genuine cynicism. His early death due to tuberculosis was the most tragic loss for the development of Estonian literature. We may find his high style not very Dickensian in form, but financially and socially he lived in Dickensian dire straits, a poor subject of his non-Estonian sponsors as the peasants formed the lower and at that time still mostly enslaved segment of the population ruled by the Baltic-German upper class.

When Dickens was born, doctor Friedrich Reinhold Kreutzwald (18031882), the author of the national epic Kalevipoeg (1861), and the actual founder of Estonian modern literature, was nine years old. As a student of medicine, Kreutzwald was influenced by German Romanticism, Herder and Schiller, and lyro-epic gothic balladry. He was a child of the enlightenment who published many texts for the education of the peasantry: sentimental poems and marvellous fairy tales, didactic and comic stories, useful calendars and partly fictional folk songs composed by himself (see also Nirk 1987: 55-64, 366-367).

Kreutzwald's heavily Ossianistic (Macphersonian) epic is his most important accomplishment with its capacity deliberately aimed at nation building. Pretty much at the same time when the Estonian 'father of songs' began his mission, Joseph Smith, the writer of the Book of Mormons (1830), founded his church of Latter-Day Saints in the USA. Because of Kreutzwald's sentimentality and identification with the suppressed and poor, his sense of humour which ranges from satiric sarcasm to juicy laughter, picturesque 
MERILAI

fantasy, but also his step by step deepening commonsensical realism, he already shares many spiritual or stylistic traits with Dickens. That involves also the amusing idiom of a 'Pickwickian sense' which is similarly not a rare quality in Kreutzwaldian expression - his poetic licence. However, we are dealing with texts written once upon a time with 'a goose feather' (steel nib), in the dim candlelight after a busy daily job.

In 2011, a new, more adequate translation, by Triinu Kartus, of the epic Kalevipoeg was released in English, something one can rely on; while the author of The Song of Hiawatha (1855), Henry Longfellow in USA, had to read it still in an inferior German version. The epic Hiawatha, too, tries to imitate the 4-feet trochee, the 8-syllable verse metre, influenced by the ancient Kalevala form, which both Estonians and Finns share (see Oinas 1985). Kalevipoeg is as much a folkloric as a literary, fictional work. It belongs to the canon "of individual verse epics, starting in the ancient world with Virgil's Aeneid, to be followed in the late Middle Ages by the French Chanson de Roland, the Spanish Cantar de Mio Cid, the German Nibelungenlied and, in the Renaissance, by Os Lusíadas (The Lusiads), a great epic written by the founder of Portuguese literature, Luis Vaz de Camões” (Talvet 2011: 506).

Aesthetically, Kalevipoeg is an artistic epic with a romantic flavour, tending more towards an epical-lyrical than a classical epic. Kreutzwald was devoted to a thrilling ballad, which had been the pinnacle of fashion in Europe for a long time. In addition, Kalevipoeg contains many a lyro-epic folk song, which forms its poetic substratum. Thus, a ballad-like lyro-dramatical-epical structure bears upon the Estonian epic, blurring the boundaries of genre and authorship in the best romantic tradition. Consequently, a twofold definition seems quite irresistible: the Kalevipoeg - a giant ballad. That is, first: a huge ballad in terms of composition, poiesis. And second: a ballad about a giant, in terms of view of content, mimesis (Merilai 2004b: 320).

Ideologically, as Jüri Talvet concludes (2011: 508), “Kreutzwald's great work had been essential in the forging of the national awakening movement in the $19^{\text {th }}$ century, and in the persistence of national memory and the ideal of freedom during the $20^{\text {th }}$ century, while under foreign occupations and repressions that the Estonians have had to suffer". Thanks to Kreutzwald, Estonian literature, along with its rapidly evolving written language, became hard to ignore by the rest of the world. He probably did more than anyone else to introduce the newborn culture to an international audience.

When Dr. Friedrich Robert Faehlmann (1798-1850), to whom we owe much for his preliminary efforts to create the national epic, had published his artificial idyllic myths, eight 'ancient tales' (1839) (see Nirk 1987: 52-55, 356), Dickens' second novel, Oliver Twist, was completed which shocked readers 
with its vivid depiction of criminal misery; as well as his third novel, Nicholas Nickleby, the same year.

At the same time, in Estonian economical life, the anachronism of the feudal system, which had caused a decrease in the incomes of the manor and the steady impoverishment of the peasantry, had compelled the Russian Emperor and the 'progressive' minority of the Baltic aristocracy to introduce some agrarian reforms, resisted by privileged conservatism. While Dickens was according to himself a "very small and not-over-particularly-takencare-of boy" (Forster 2006: 13), the abolition of serfdom in the provinces of Estonia and Livonia eventually took place in 1816 and 1819, followed by some supplementary reforms. As late as in the 1860s, the peasants finally received the right to change their domicile, granted with an opportunity to pass from the work-rent to the money-rent with the prospect of full ownership of their farms. Before all that, until the $19^{\text {th }}$ century, a healthy male field hand, skilled craftsman or a whole family (equivalent to a horse as a rule of thumb) had been much cheaper even than Uncle Tom in New Orleans' slave market in the 1830s: up to 100 roubles compared with around 1000 dollars (as a good horse cost about $\$ 100$ in the $19^{\text {th }}$ century USA) (Kotlikoff 1979: 500-501; Evans 1962: 199-201). However, a human being could even cost less than 4 roubles in Livonia before 1765 (Transehe-Roseneck 1890: 200). ${ }^{8}$ Just as a footnote we might add that, because the American Civil War in the 1860s turned out to be very conducive to Estonia's national awakening, incidentally, as the prices of linen sky-rocketed in Europe which opened the way for the peasantry to purchase their freedom from the manor.

Subsequently, Estonia entered the capitalist era that was marked by a tremendous increase in the cultural activity of the people - a splendid conjuncture, as it was said in Renaissance times. The struggle against the barons, for the emancipation and self-sufficiency was sharply speeded up and took on many new forms. The popular Estonian newspapers, first weeklies, later dailies Pärnu Postimees (The Pärnu Postman) and Eesti Postimees (The Estonian Postman) were launched by Johann Voldemar Jannsen (1819-1890) (see Nirk 1987: 65-69), anti-aristocracy articles were published, especially

8 Astaf von Transehe-Roseneck, Gutsherr und Bauer in Livland im 17. und 18. Jahrhundert (1890: 200): "Lostreiber und deren Kinder werden zuweilen verkauft, oder gegen andere Sachen, gegen Pferde, Hunde, Pfeifenköpfe u. dgl. verstaucht, die Menschen sind hier nicht so theuer als ein Negr in den Amerikanischen Kolonien, einen ledigen Kerl kauft man für 30 bis 50, wenn er ein Handwerk versteht, Koch, Weber u. dgl. ist, auch wohl für 100 Rubel; ebensoviel giebt man für ein ganzes Gesinde (die Eltern nebst ihrer Kinder), für ein Magd selten mehr als 10 und für ein Kind etwa 4 Rbl.” 
edited by Carl Robert Jakobson (1841-1882) (see Nirk 1987: 77-78) in the paper Sakala (which is the name of an ancient county in South Estonia that once so fiercely resisted the German crusaders in the $13^{\text {th }}$ century). New schools, cultural and agricultural societies and private businesses were established, textbooks, poetry, fiction and criticism were published, choir song and brass band festivals were held. The first national song festival, now the trademark of Estonia, in a sense its cultural core text on the deepest level, close to religion, was held in 1869 in Tartu, organized by Jannsen, celebrating the $50^{\text {th }}$ anniversary of the abolition of serfdom. Achieving almost $100 \%$ literacy, the Estonians educated and sang themselves into a modern nation. Of course, not everything developed so smoothly, as there were also many open or less visible quarrels among between Estonians. At the beginning, the Czarist policy to some extent even supported secretly the local national movement as it clearly undermined the key position of the Baltic Germans in the governance of the Empire. At the end of the century, by the time of late Dickens, however, a strong wave of Russification took place aiming to suppress both Estonians and their German-speaking upper class, which caused a certain decline in the national movement. But it was too late already: patriotism eventually gained its victory, and a new cultural society was formed.

By the time when the great novels of 'our mutual friend' had already been written, except the unsolved mystery with Edwin Drood, and nine years later when Charles Baudelaire's Fleurs du mal were published in Paris (in 1857), a young woman stood at the birth of Estonian literature with her Waino-Lilled (Meadow Flowers, 1866) and Emmajöe Öpik (Nightingale of the Embach River, 1867) - an entirely new phenomenon on the cultural scene of that time. This extraordinary, emancipated woman - Lydia Emilie Florentine Jannsen, editor Jannsen's daughter and his eager hand in newspaper work, also Kreutzwald's keen admirer - became the matriarch of the fairly rich women's poetry in Estonian. Lydia Koidula (1843-1886) (see Nirk 1987: 73-77, 366; Puhvel 1995), which was her (initially designed as male) pen-name suggestive of the Estonian word for 'dawn', expressed strongly growing national sentiments, particularly patriotism. Her epigonic poems, stories and comedies were mainly free adaptations in the tradition of German Biedermeier (Liedertafel), still playing a prominent role in early Estonian cultural history. From Kreutzwald's epic and fairy tales and Koidula's poetry and plays onwards, we can speak of a continuity of belles-lettres written by Estonians in their mother tongue and for themselves.

In addition, before we move to Eduard Vilde, historical resistance stories by Eduard Bornhöhe (1862-1923) (see Nirk 1987: 87-88, 355) and the comical stories and tragedies by August Kitzberg (1855-1927) (see Nirk 
1987: 105-108, 365) are also worth mentioning with Dickensian respect. Sharply condemning the tyranny of the alien feudal order, Bornhöhe depicted the struggle of the native people in a spirit of youthful enthusiasm and exalted romanticism. Kitzberg's finest short stories and postromantic plays, together with the counterparts by Vilde, helped raise Estonian literature to European standards. Also Oskar Luts (1887-1953), a writer of humorous and sentimental scenes from life, a talented story-teller by the grace of God, has been occasionally interpreted in the vein of Dickens (for example, by the leading critic Ants Oras). Especially his biographical school novel Kevade (Spring, 1913), ensured the enduring popularity of its author, for his cheerful or melancholic, nostalgic characters, his sympathy towards the youngsters with their pranks or troubles, as well as his vivid, reader-driven colloquialism.

By that time, alas, good old Charles was already as silent and straight as a doornail, knowing nothing about the trials and tribulations of the northern neighbours of Latvians and the southern relatives of Finns. However, the nation, only taking its time, saw itself haunted by the spirit of Dickens, as we may consider Vilde his Estonian reincarnation.

\section{Eduard Vilde (1865-1933) - The Estonian Dickens}

Eduard Vilde (see Nirk 1987: 98-105, 397-398; Ots 2000; Haug 1999), active half a century after Dickens, could be taken as a counterpart of Dickens in many ways, although he was directly influenced by the literature published in German or Estonian and could not read English. Vilde, Eduard Bornhöhe's cousin, was the first Estonian prose writer to achieve the recognition of a living classic. He wrote the first original, lengthy historical and socio-critical novels: Külmale maale (To the Frozen North, 1896), Astla vastu (Against the Pricks, 1898), Raudsed käed (Iron Hands, 1898/1910), Mahtra sõda (Mahtra War, 1902), Kui Anija mehed Tallinnas käisid (When the Men from Anija Went to Tallinn, 1903), Prohvet Maltsvet (Prophet Maltsvet, 1908) - these three form the so-called historical trilogy -, and Lunastus (Redemption, 1909). Vilde's collected works in 33 volumes included also witty short stories, plays, some travelogues and many feuilletons.

As Dickens, Vilde began as a prolific journalist and serial writer. His early stories are adventurous, entertaining reading with sentimental clichés. As he soon adopted a more critical and realistic style, his humour, which equally may have been inspired by the stories about Mr. Pickwick or Tom Sawyer, remained a distinguishing feature of his writing. He had even translated a feuilleton by Mark Twain. The phrase 'Vilde's joke' became an idiom often 
used by his keen readers. At the end of the 1890s, Vilde began to spend years in Berlin, Copenhagen, Helsinki, Stuttgart, Tirol and elsewhere where he developed a fascination for a materialist world view, social democracy and the method of critical realism. He also got acquainted with Karl Kautsky and Clara Zetkin, the leading Marxists in Europe; they occasionally even helped him with travel documents, some printing space and royalties, although not much. As an emigrant, first trying to escape the Czarist authorities because of his revolutionary activity around 1905, but later mostly for his own convenience, he once tried to settle down in New York where his wife worked as an editor. However, he quickly fled back to Europe after trouble with the immigration service, which held him in custody in Ellis Island for a while, due to the insinuations by American Estonians: a dubious socialist tries to smuggle himself in - watch out. For two years, since 1919, he was also a diplomatic representative of the new-born Estonian Republic in Berlin.

Vilde's second wife, the journalist Linda Jürman, was a socialist feminist. We may consider her spouse himself as one of the first Estonian feminists as he passionately fostered the emancipation of women, the 'double subalterns' (see Spivak 1988). Alas, in his personal life, unfortunately childless, Vilde tended to be a kind of Casanova, as he self-ironically used to mock himself (as one of his last short stories was entitled "Casanova's Farewell"). So he could be typically patriarchal and ambivalent, too. Apart from that, Vilde and Jürman, in their political activity, strictly rejected Russian revolutionary socialists and bolsheviks with their murderous leaders, as well as the German fascists later, as the couple advocated personal and national freedom, independence, peace and human dignity.

While Vilde was exploring western Europe, between the two revolutions in 1905 to 1917, Émile Zola's Naturalism was the latest delight there. Vilde's socially critical novels started to depict life in $19^{\text {th }}$-century Estonia: forced unpaid work still owned by the anachronistic barons and the peasant riots against it, early urban capitalism, overwhelming religious fanaticism, together with the mass exodus of Estonians to South and East Russia, Crimea and Siberia, in the hope of becoming masters of their own, and the waiting for the delusional White Ship of Our Saviour. Vilde's bulky short stories and novels expressed irony and sarcasm about an obsolete feudalist as well as the rotten capitalist world. He exposes the vices of all those greedy exploiters, the hypocricy of a degenerated society with its suppressive rules. Mostly he describes, sometimes adopting a documentary mode, the life of the peasantry - the Hugoesque miserables or stubborn rebels - under the yoke of their cruel landlords. Grim rituals like corporal punishment and sexual harassment were for Vilde the symbols of an archaic world. His novels are often spilling 
blood: he lashed the barons and their heartless servants as ruthlessly as they had tortured his fellow inferiors. A slightly sadistic whiplash together with some erotic arousal is almost always there in his works. Social ranks and blind selfishness rule our vale of tears to be overcome in a more humane and not too distant future.

Vilde's last novel, Mäeküla piimamees (The Dairyman of Mäeküla, 1916), is Estonia's first psychological and even psychoanalytical novel, with its eternal triangle, and the signing of a contract with Evil. Vilde transfers the peasantbaron relationship closer to the present when the latter can not use violence with their labour any more. A freaky manor owner, the old bachelor von Kremer loses his heart to a young peasant woman, Mari. Half a century earlier it would have been easier to seduce or rape her. However, the brutal feudal ius primae noctis, the 'right of the first night', is no longer applicable. Von Kremer decides to make an (in)decent deal: he offers Mari's husband, the smallholder Prillup, the position of his manor dairyman in exchange for sexual pleasures with his wife. At first she strictly refuses to get involved in this kind of hideous business. Greedy silly Prillup tries to flatter her and does whatever else it takes. At last Mari, an innocent child of nature, agrees, of her own boredom, feeling pity for the two pathetic men, and her husband gets the desired job. This fortune leads to the poor man's downfall, as he becomes the laughingstock of the village and falls apart inwardly, and soon dies, a lunatic wreck. Mari abandons von Kremer and moves to the city with her two stepchildren (their mother, Mari's older sister, Prillup's first wife, had died). She hopes to become self-reliant getting rid of all that nasty, humiliating trash.

Vilde also succeeded as a mature playwright. His comedy Tabamata ime (The Inscrutable Mystery, 1912) is an attack on the fake posh attitudes of the Estonian upstarts with their desire to find a national genius. As a result, an aspiring pianist overextends his skills and loses his mind.

Vilde's second important play, Pisuhänd (The Hobgoblin, 1913) mocks the bad manners of the parvenus and suspicious ways of how they achieved their status and wealth. (Alas, a couple of decades later, the Soviet regime expropriated almost all their fortunes, even quite insignificant ones.) As Loone Ots (2000: 312) puts it: "Plotted tightly and ingeniously, the play includes memorable characters and is written in a language resembling the witty dialogue of a George Bernard Shaw or an Oscar Wilde. Vilde's Pisuhänd is genuine high comedy with a distinctly Estonian flavour."

Although this fascinating comparative subject matter requires a much fuller treatment, one might summarize that Vilde was 'eminently the people's author', not unlike his English counterpart Dickens whose essence in Estonian literature he the most evidently represents. However, his style 
MERILAI

developed towards more explicitness, elaborate imagery and poetic rhythm as his occasionally loose 'Pickwickian expression' of day-to-day journalism constantly receded. Like Dickens, an author of bestsellers and very popular in his lifetime (except for a few snobbish, neo-romantic critics with their updated standards), Vilde was also widely read and interpreted in Soviet Estonia when he acquired a distorted reputation as a pro-communist writer (while his criticism of their disastrous regime was kept a secret by the censorship). Therefore, what John Kucich and Dianne Sadoff wrote in The Oxford Encyclopedia of British Literature (2006: 155), could in principle be applicable to Vilde, too: "Karl Marx affirmed that Dickens "issued to the world more political and social truths than have been uttered by all the professional politicians, publicists and moralists put together."” George Bernard Shaw did Marx one better, finding Great Expectations to be a more seditious book than Das Kapital.

As literary scholar Endel Nirk has said (1987: 105), it fell to Eduard Vilde with his vigorous critical realism and broad range of subject matter to carry Estonian fiction to the level of maturity. Later on, the genre of Pip and other youngsters - Bildungsroman ${ }^{9}$ - also aligns with the tradition, most prominently represented by Anton Hansen Tammsaare's monumental Tõde ja õigus I-V (Truth and Justice, 1926-1933) and Karl Ristikivi's series of existential novels (since the 1930s to 1970s in Estonia and in exile, Sweden; he was born exactly a hundred years after Dickens). And, of course, historical narratives by Jaan Kross "with Estonia as its protagonist” (Salumets 2000: 174).

\section{Appendix}

Thus, willy-nilly, guided by some unavoidable Marxist considerations, in spite of their apparent incongruity with the solitary and close-to-nature mentality peculiar to Estonians, which suggests quite different psychological attitudes and social solutions, we have arrived at a Marxist model for capitalist society: how did it actually work and how does it still saliently inform theories such as feminism and postcolonialism. According to the orthodox beliefs, there are two different, antagonistic classes within a culture, born of core material interests (basic instincts) - a split economy producing a split reflexivity.

The chart presented below was sketched some three decades ago while I was a doctoral student and had to listen to the dull lecturers on 'red philosophy'. I find this X-Ray sufficient enough to elucidate rather adequately the Marxist

9 The notion of Bildungsroman (development novel) was actually coined in Tartu in 1819, by Johann Karl Simon Morgenstern (1770-1852), professor of aesthetics. 
system. And this really makes one wonder, why on earth nobody, among the billions ever influenced by Marxism in modern history, had never tried to visualize it?

\section{MARXIST MODEL OF CIVIL SOCIETY:}

\section{CLASS ANTAGONISM}

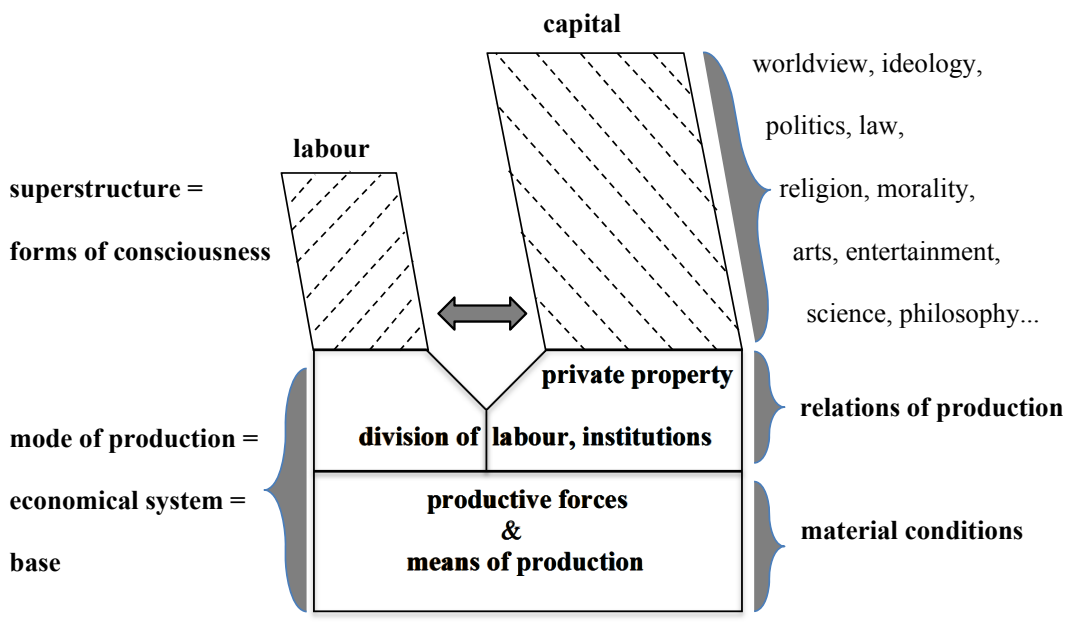

Can a slave, proletarian, subaltern or woman - double subaltern - even speak, do they have their own, unendorsed consciousness and language? Here 'private property' (actually all individual privileges in general, but especially in the economic sense) is the locus crucis - the holy mantra of 'the root of all evil' (as community implies integrity and equality by nature, rather than utilization by fellow beings), to be abolished by the (religious, proletarian, postcolonial, feminist) revolution (emancipation). The chart brings into focus the dogma of two separate, fatally conflicting - dominating versus suppressed - cultures (mental constructions). However, this, quite simply, constitutes a logical fallacy: the antagonism - supposedly inherent in the superstructure, and allegedly curable only in communism, a society without private property of main means of production (which should belong to the whole society), and, consequently, without misappropriated surplus value and major fighting blocks -, was heavily oversimplified and its reach overextended. Culture does not just work in that primitive, black and white a way: it is much more and undeniably holistic as a whole and at the same time in many ways more diverse inwardly. It is not only a matter of one-to-one synchronic match to its base - which, of course, is also definitely there - but it is also fundamentally 
MERILAI

diachronic, widely spread in space-time, historically and globally, with its own many-valued logic and dynamics which is largely independent of its particular substructure. Otherwise, on a purely economic level, Karl Marx was nothing short of a genius. After all, he diagnosed social alienation, predicted global riots and what else - that much is definitely true.

Nevertheless, today, Karly should be as dead as was Marley in A Christmas Carol: to end with. However, is he indeed? And what about Charlie, or his virtual soulmate Eedi?

\author{
Arne Merilai \\ arne.merilai@ut.ee \\ Tartu Ülikool \\ Kultuuriteaduste ja Kunstide Instituut \\ Ülikooli 16 \\ 51014 Tartu \\ EESTI
}

\title{
References
}

Evans Jr., R. 1962. The Economics of American Negro Slavery, 1830-1860. - Aspects of Labour Economics. Universities-National Bureau: Princeton University Press, 185-256 (http://www.nber.org/chapters/c0606.pdf, retrieved 01.07.2014).

Forster, J. 2006. Life of Charles Dickens. London: Diderot Publishing [London: Cecil Palmer, 1872-1874] (http://www.lang.nagoya-u.ac.jp/ matsuoka/CDForster-1.html, retrieved 01.07.2014).

Haug, T. 1999. Eduard Vilde. - ELM: Estonian Literary Magazine, 8, Spring, 2-3 (http://www.einst.ee/literary/spring99/index.html, retrieved 01.07.2014).

Klotz, V. 1960. Geschlossene und offene Form im Drama. Literatur als Kunst. München: Hanser.

Kotlikoff, L. J. 1979. The Structure of Slave Prices in New Orleans, 1804 to 1862. Economic Inquiry, XVII, 4, October: 496-518 (doi: 10.1111/j.1465-7295.1979. tb00544.x, retrieved 01.07.2014).

Kucich, J., Sadoff, D. F. 2006. Charles Dickens. - D. S. Kastan et al., ed., The Oxford Encyclopedia of British Literature, 1. Oxford: Oxford University Press, 154-164.

Liiv, S., Tofantšuk, J. 2013. Dickens in Estonia. - M. Hollington, ed., The Reception of Charles Dickens in Europe. London-New York: Bloomsbury Academic, 511-514, 654-655.

Merilai, A. 2004a. Genius of Estonian Poetry - Kristian Jaak Peterson. - ELM: Estonian Literary Magazine, 19, Autumn, 4-9 (http://elm.estinst.ee/issue/19/ genius-estonian-poetry-kristian-jaak-peterson, retrieved 01.07.2014). 
The Ages of Dickens in Estonian Literature

Merilai, A. 2004b. Kalevipoeg as a Lyrical Epic: A Question of the Genre. - Keel ja Kirjandus, 4, 320.

Nirk, E. 1987. Estonian Literature: Historical Survey with Biobibliographical Appendix, 2 ed. Tallinn: Perioodika.

Viiding, K., Orion, J., Päll, J., eds., 2007. O Dorpat, Urbs Addictissima Musis...: Valik 17. Sajandi Tartu Juhuluulet. Tallinn: Eesti Keele Sihtasutus, 2007.

Oinas, F. J. 1985. Studies in Finnic Folklore: Homage to the Kalevala. Helsinki: Finnish Literary Society. Suomalaisen Kirjallisuuden Seuran Toimituksia, 387 / Indiana University Publications: Uralic and Altaic Series, 147.

Ots, L. 2000. Eduard Vilde. - S. Serafin, ed., Dictionary of Literary Biography, 220. Twentieth-Century Eastern European Writers: Second Series. Detroit etc.: A Bruccoli Clark Layman Book / The Gale Group, 309-313.

Phillips, W. A. 1911. Krüdener, Barbara Juliana, Baroness von. - Encyclopredia Britannica, $11^{\text {th }}$ ed., vol. 15 (http://en.wikisource.org/wiki/1911_Encyclop\%C3\% A6dia_Britannica, retrieved 01.07.2014).

Puhvel, M. 1995. Symbol of Dawn: The Life and Times of the $19^{\text {th }}$-Century Estonian Poet Lydia Koidula. Tartu: Tartu University Press.

Sachris, N. B. 2004. Addenda to Our Knowledge of Juliane B. von Krüdener. Akadeemia, 11, 2515-2516.

Salumets, T. 1991. Unterwanderte 'Normendestruktion': Zur Poetologie des Sturmund-Drang-Dramas. - Euphorion, 85, 70-84.

Salumets, T. 2000. Jaan Kross: Negotiating Nation. - Interlitteraria, 5, 171-185.

Spivak, G. C. 1988. Can the Subaltern Speak? - C. Nelson, L. Grossberg, ed., Marxism and the Interpretation of Culture. Basingstoke: Macmillan Education, 271-313.

Talvet, J. 2011. Kalevipoeg, a Great European Epic. - F. R. Kreutzwald. Kalevipoeg: Eesti rahvuseepos. / Kalevipoeg: The Estonian National Epic. Trans. Triinu Kartus. Tartu-Tallinn: Eesti Kirjandusmuuseum / Estonian Literary Museum, Kunst, 504-510.

Transehe-Roseneck, A. von. 1890. Gutsherr und Bauer in Livland im 17. und 18. Jahrhundert. Abhandlungen aus dem Staatswissenschaftlichen Seminar zu Strassburg i. E., 7. Herausgegeben von G. F. Knapp. Strassburg: Verlag von Karl J. Trübner. 